\title{
Thermal Volume Change of Unsaturated Silt under Different Stress States and Suction Magnitudes
}

\author{
John S. McCartney ${ }^{1, a}$ \\ ${ }^{1}$ University of California San Diego, Department of Structural Engineering, 9500 Gilman Dr, La Jolla, CA 92093-0085, USA
}

\begin{abstract}
This paper presents an evaluation of the thermal volume change of compacted specimens of the same type of silt under a wide range of stress states, initial void ratios, and suction magnitudes. Stress states include both isotropic and anisotropic conditions with varying principal stress ratios, as well as normally consolidated and overconsolidated conditions. Initial void ratios range from 0.60 to 0.86 , spanning very dense to loose conditions. Suctions evaluated range from saturated conditions, to low suctions in the funicular range, to suctions corresponding to residual saturation conditions. For the same soil, wide variations in thermal volume change are observed. Thermal contraction is observed for normally consolidated conditions regardless of the initial degree of saturation. Different mechanisms of thermal volume change can be used to explain the results, ranging from thermally-induced pore water pressure dissipation, to thermal collapse, to thermally-accelerated creep.
\end{abstract}

\section{Introduction}

Several studies have recently been performed to characterize the drained thermal volume change response of compacted specimens of Bonny silt under different initial conditions and stress states using different experimental approaches (Coccia and McCartney 2012; Vega and McCartney 2015; Coccia and McCartney 2015, 2016b; Alsherif and McCartney 2015, 2016; Shanina and McCartney 2016), including both saturated and unsaturated conditions. The results from these different studies have yielded thermal volume changes that are within the same order of magnitude of each other, but differences in the trends are observed in some cases. This paper provides a critical review of the reasons leading to different responses in the tests from the studies mentioned above. This includes an assessment of the role of the initial void ratio, the role of compaction conditions (wet or dry of optimum), the role of stress history (i.e., the overconsolidation ratio, OCR), the role of anisotropic stress state (the principal stress ratio $\mathrm{K}=\sigma_{3} / \sigma_{1}$ ), and the initial degree of saturation.

\section{Background}

The thermo-mechanical behavior has been characterized for a wide range of saturated soils (Campanella and Mitchell 1968; Demars and Charles 1982; Hueckel and Baldi 1990; Towhata et al. 1993; Burghignoli et al. 2000; Sultan et al. 2002; Cekerevac and Laloui 2004; AbuelNaga et al. 2007; Coccia and McCartney 2012; Vega and McCartney 2015) and unsaturated soils (Romero 1999; Saix et al. 2000; Romero et al. 2005; Tavalli et al. 2007;

\footnotetext{
${ }^{a}$ Corresponding author: mccartney@ucsd.edu
}

Salager et al. 2008; Tang et al. 2008; Uchaipichat and Khalili 2009; Coccia and McCartney 2015, 2016b, Alsherif and McCartney 2015, 2016, Shanina and McCartney 2016). The results from some these studies have been compared by McCartney (2012) and Laloui et al. (2015), who found that the soil mineralogy and the OCR were the primary variables that affected the magnitude and sign of the thermal volume changes. Contraction is expected to occur for normallyconsolidated soils and expansion is expected for heavily overconsolidated soils, with a transitional behavior as the OCR increases.

Vega and McCartney (2015) confirmed trends in thermal volume change with stress history observed in the literature, but found that cyclic heating and cooling may lead to continued thermal volume changes in the direction observed during the initial heating cycle (i.e., either expansion or contraction). In addition to stress history, Coccia and McCartney (2012) found that anisotropic stress states may lead to different magnitudes of thermal axial strains in saturated soils under different principal stress ratios. Further, if the major principal stress is close to normally consolidated conditions, contraction may occur in this direction. However, as the principal stress ratio decreases, it is possible that expansion can occur in the minor principal stress direction. In addition to the stress state, the path of heating and stress changes may affect the magnitude and direction of thermal volume changes. Similar observations have been observed for unsaturated silt by Shanina and McCartney (2016). Alsherif and McCartney (2015) found that heating at low suctions leads to contraction while heating at high suctions leads to 
expansion for similar stress states and temperature changes. This behavior was explained using different hardening and softening mechanisms by Alsherif and McCartney (2016). The thermal volume change of unsaturated soils considering changes in degree of saturation during heating was recently considered by Coccia and McCartney (2016a, 2016b). Inconsistent trends in thermal contraction were observed for normally consolidated specimens with decreasing degree of saturation, similar to the lack of trend with this variable observed by Uchaipichat and Khalili (2009). Coccia and McCartney (2016a) proposed that thermal volume change may instead be due to thermally-accelerated secondary creep under the previously applied mechanical stress.

\section{Material}

The relevant geotechnical properties of Bonny silt are summarized in Table 1. The liquid and plastic limits of the soil are 25 and 21, respectively, measured in accordance with ASTM D4318, and the fines content is $83.9 \%$. Accordingly, the silt is classified as ML (inorganic low plasticity silt) according to the Unified Soil Classification System (USCS, ASTM D2487).

Table 1. Bonny silt characteristics.

\begin{tabular}{|c|c|}
\hline Parameter & Value \\
\hline $\mathrm{D}_{10}$ & $<0.0013 \mathrm{~mm}$ \\
\hline $\mathrm{D}_{30}$ & $0.022 \mathrm{~mm}$ \\
\hline $\mathrm{D}_{50}$ & $0.039 \mathrm{~mm}$ \\
\hline \% Fines smaller than $75 \mu \mathrm{m}$ & $83.9 \%$ \\
\hline \% Sand size & $16.1 \%$ \\
\hline Liquid Limit, LL & 25 \\
\hline Plastic Limit, PL & 21 \\
\hline Plasticity Index, PI & 4 \\
\hline
\end{tabular}

All of the Bonny silt specimens evaluated in this study were prepared using static compaction to different dry unit weights at different compaction water contents. The compaction curves corresponding to the standard and modified Proctor compaction energies are shown in Figure 1 for reference. The specimen sizes were different in each of the studies assessed, as summarized in Table 2. The specimen size is not expected to play an important role as the silt is relatively fine-grained, but there may be some differences in the transient response.

Table 2. Specimen sizes evaluated.

\begin{tabular}{|c|c|c|}
\hline Study & $\begin{array}{c}\text { Height } \\
\text { (mm) }\end{array}$ & $\begin{array}{c}\text { Width or } \\
\text { Diameter } \\
\text { (mm) }\end{array}$ \\
\hline $\begin{array}{c}\text { Coccia and McCartney (2015, } \\
\text { 2016b) }\end{array}$ & 25.4 & 63.5 \\
\hline $\begin{array}{c}\text { Alsherif and McCartney (2015) } \\
\text { S-T }\end{array}$ & 71.1 & 35.6 \\
\hline $\begin{array}{c}\text { Alsherif and McCartney (2015) } \\
\text { T-S }\end{array}$ & 71.1 & 35.6 \\
\hline Vega and McCartney (2015) & 25.4 & 83.0 \\
\hline Shanina and McCartney (2016) & 177.8 & 177.8 \\
\hline
\end{tabular}

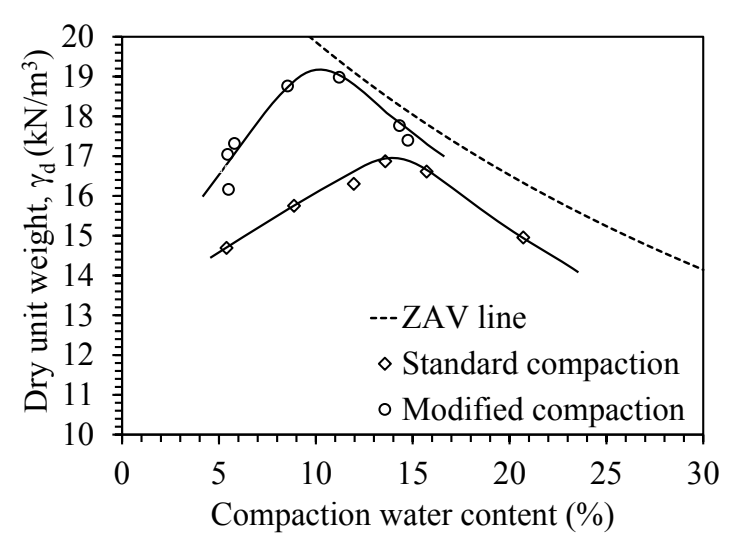

Figure 1. Compaction curves for Bonny silt

The compaction conditions and initial conditions at the start of heating from the different studies is presented in Table 3. A wide range in densities and initial water content values has been assessed, ranging from wet to dry of optimum.

Table 3. Initial compaction conditions.

\begin{tabular}{|c|c|c|c|}
\hline Study & $\begin{array}{c}\mathbf{w}_{\mathbf{c}} \\
(\%) \\
\end{array}$ & $\begin{array}{c}\gamma_{\mathrm{d}, \mathrm{c}} \\
\left(\mathbf{k N} / \mathbf{m}^{3}\right)\end{array}$ & $\mathbf{e}_{\text {initial }}$ \\
\hline $\begin{array}{c}\text { Coccia and McCartney } \\
(2015,2016 b)\end{array}$ & 13.9 & 14.2 & 0.80 \\
\hline $\begin{array}{c}\text { Alsherif and } \\
\text { McCartney (2015) S-T }\end{array}$ & 10.5 & 15.7 & 0.68 \\
\hline $\begin{array}{c}\text { Alsherif and } \\
\text { McCartney (2015) T-S }\end{array}$ & 10.5 & 15.7 & 0.68 \\
\hline $\begin{array}{c}\text { Vega and McCartney } \\
(2015)\end{array}$ & 15.0 & 16.6 & 0.60 \\
\hline $\begin{array}{c}\text { Shanina and } \\
\text { McCartney (2016) }\end{array}$ & $\begin{array}{l}15.8 \\
18.2\end{array}$ & 16.2 & 0.64 \\
\hline
\end{tabular}

The different compaction conditions were found to correspond to different hydraulic properties for the same soil. Specifically, the parameters of the soil-water retention curve (SWRC) model of van Genuchten (1980) $\left(\alpha_{\mathrm{vG}}, \mathrm{n}_{\mathrm{vG}}\right)$ reported by each of the studies are summarized in Table 4. All of the studies observed or assumed that Bonny silt has a residual degree of saturation $\mathrm{S}_{\mathrm{r} \text {,res }}$ of 0.06. It is likely that differences in the hydraulic conductivity and thermal conductivity are also present, but these were not measured in all of the studies.

Table 4. Hydraulic properties for the specimens with different compaction conditions.

\begin{tabular}{|c|c|c|}
\hline Study & $\boldsymbol{\alpha}_{\mathbf{v G}}\left(\mathbf{k P a}^{-1}\right)$ & $\mathbf{N}_{\mathbf{v G}}$ \\
\hline $\begin{array}{c}\text { Coccia and McCartney } \\
(2015,2016 \mathrm{~b})\end{array}$ & 0.20 & 1.30 \\
\hline $\begin{array}{c}\text { Alsherif and McCartney } \\
(2015) \text { S-T }\end{array}$ & 0.33 & 1.61 \\
\hline $\begin{array}{c}\text { Alsherif and McCartney } \\
(2015) \text { T-S }\end{array}$ & 0.33 & 1.61 \\
\hline $\begin{array}{c}\text { Vega and McCartney (2015) } \\
\text { Shanina and McCartney } \\
\text { (2016) }\end{array}$ & 0.11 & $\mathrm{NR}$ \\
\hline
\end{tabular}




\section{Experimental Approaches}

Each of the different studies presented in the tables above followed different testing approaches, which are discussed in more detail in the respective papers. Coccia and McCartney $(2015,2016 \mathrm{~b})$ used an isotropic thermal cell with internal deformation measurements along with a flow pump used to control the suction in drained heating tests and track changes in the degree of saturation. Alsherif and McCartney $(2015,2016)$ used a modified triaxial cell with suction control using the vapor flow technique to study the thermal volume change and shear strength of soils under high temperatures and suction magnitudes. Vega and McCartney (2015) used a thermal oedometer test and evaluated the cyclic heating and cooling response of saturated silt specimens. Shanina and McCartney (2016) used a thermal true-triaxial cell with suction control on one face of a cubical specimen and principal stress control on the other five faces to study the role of stress-induced anisotropy.

The initial stress state evaluated in each of the studies was different, as summarized in Table 5. It is clear that the void ratios at the start of heating are lower than those induced by compaction due to the application of the target stress state or changes in the initial suction.

Table 5. Initial stress state prior to heating.

\begin{tabular}{|c|c|c|c|c|}
\hline Study & $\begin{array}{c}\text { OCR } \\
\text { range }\end{array}$ & $\begin{array}{c}\text { Principal } \\
\text { stress } \\
\text { ratio } \\
\end{array}$ & $\mathbf{e}_{\text {heating }}$ & $\begin{array}{l}\Psi_{\text {heating }} \\
(\mathbf{k P a})\end{array}$ \\
\hline $\begin{array}{c}\text { Coccia and } \\
\text { McCartney } \\
(2015,2016 b)\end{array}$ & 1 & 1 & $\begin{array}{l}0.754 \\
\text { to } \\
0.796\end{array}$ & 30 \\
\hline $\begin{array}{l}\text { Alsherif and } \\
\text { McCartney } \\
\text { (2015) S-T }\end{array}$ & $\begin{array}{c}12 \text { to } \\
22\end{array}$ & 1 & $\begin{array}{l}0.40 \\
\text { to } \\
0.57\end{array}$ & $\begin{array}{l}168, \\
291\end{array}$ \\
\hline $\begin{array}{l}\text { Alsherif and } \\
\text { McCartney } \\
\text { (2015) T-S }\end{array}$ & 1 to 3 & 1 & $\begin{array}{c}0.55 \\
\text { to } \\
0.62\end{array}$ & 40 \\
\hline $\begin{array}{c}\text { Vega and } \\
\text { McCartney } \\
(2015)\end{array}$ & $\begin{array}{c}1 \text { to } \\
31\end{array}$ & 1 & $\begin{array}{c}0.51 \\
\text { to } \\
0.6\end{array}$ & 0 \\
\hline $\begin{array}{c}\text { Shanina and } \\
\text { McCartney } \\
(2016)\end{array}$ & 1 & $\begin{array}{c}1.0,0.7 \\
0.5\end{array}$ & 0.576 & 20,10 \\
\hline
\end{tabular}

Note: Principal stress ratio $=($ Minor principal stress/Major principal stress), $\psi_{\text {heating }}$ and $\mathrm{e}_{\text {heating }}$ denote the suction and void ratio at the start of heating

\section{Results}

\subsection{Coccia and McCartney $(2015,2016 b)$}

The thermal volume changes for a saturated, compacted silt specimen reported by Coccia and McCartney (2015) are shown in Figure 2, along with the results from a similar isotropic true-triaxial test presented by Coccia and McCartney (2012) for comparison. Both the heating and cooling cycles are shown in the figure, and a similar plastic contraction behavior during heating and elastic contraction during cooling is observed in both tests. This confirms that thermal volume change experiments on specimens with very different shapes and sizes are similar.

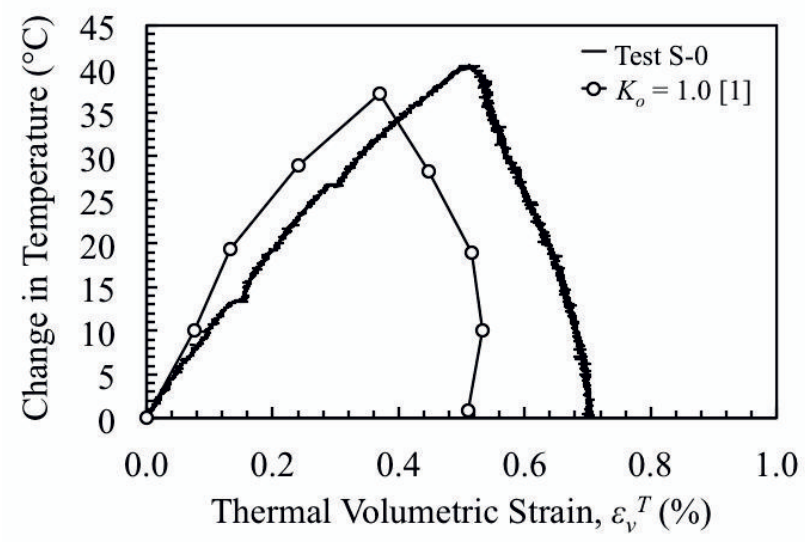

Figure 2.Thermal volume changes for isotropic tests on saturated, compacted silt specimens performed by Coccia and McCartney (2012) [1] and Coccia and McCartney (2015)

The results from tests on specimens reported by Coccia and McCartney (2016b) having different initial degrees of saturation are shown in Figure 3. The thermal volumetric strains for a change in temperature of $40{ }^{\circ} \mathrm{C}$ ranges from 0.3 to $0.75 \%$. Although no clear trend in the thermal volume change with the initial degree of saturation is observed for these tests, this may be because the degree of saturation is not the only variable controlling the magnitude of thermal volume change. Coccia and McCartney $(2016 \mathrm{a}, 2016 \mathrm{~b})$ proposed that the thermal volume change may not be due to the dissipation of thermal excess pore water pressures, which would naturally be associated with the quantity of water in the specimen. Instead, they proposed that the thermal volume change is due to thermally-accelerated secondary compression under the previously applied change in mean stress.

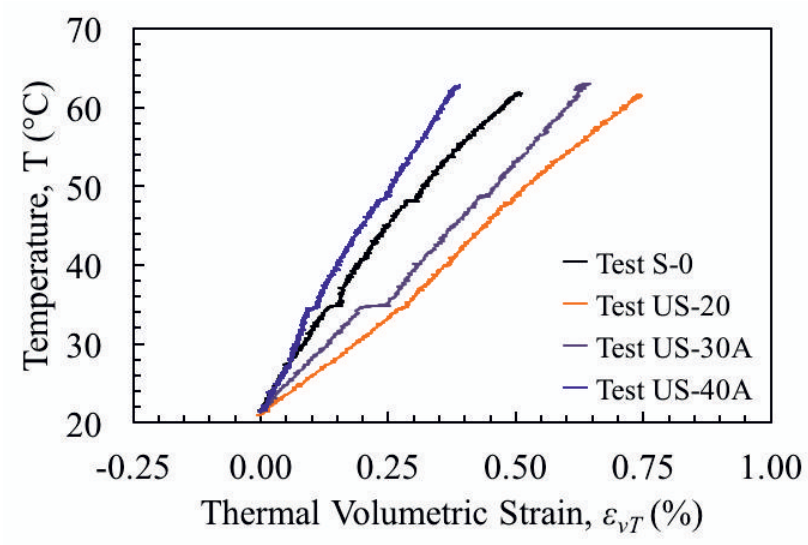

Figure 3.Thermal volume changes for specimens with different initial degrees of saturation (Coccia and McCartney 2016b) 


\subsection{Alsherif and McCartney (2015)}

The thermal volume change of specimens that were heated under relatively low suctions of $40 \mathrm{kPa}$ and different confining stresses are shown in Figure 4. Contraction is observed in all of the tests, with a magnitude similar to those observed by Coccia and McCartney (2016b) despite the lower initial degree of saturation and lower initial void ratio. The applied confining stress does not have a major effect on the thermal contraction. The results for specimens that were heated under high suction magnitudes of $291 \mathrm{MPa}$ and different confining stresses are shown in Figure 5. In this case, expansion is observed in all of the tests. This indicates that the application of high suction magnitudes induces a hardening effect that has a similar effect to a high OCR.

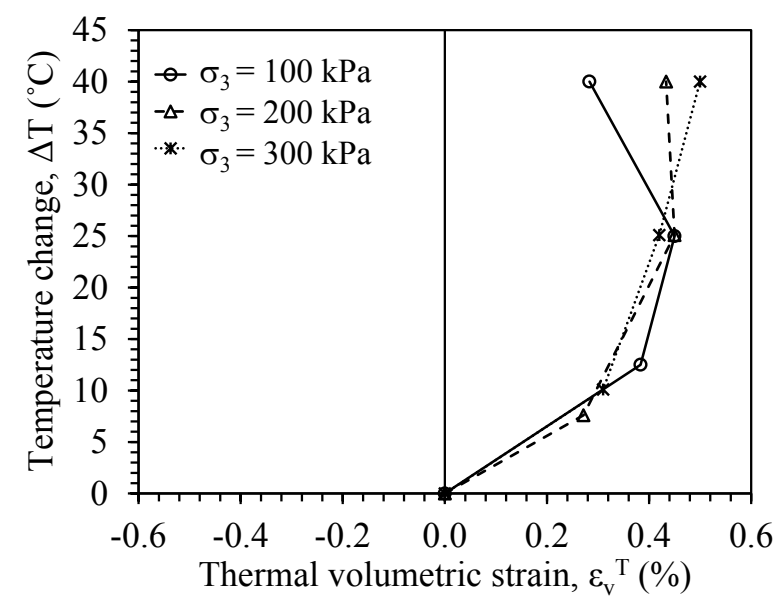

Figure 4. Thermal volume changes of specimens heated under a suction magnitude of 0.4 MPa (Alsherif and McCartney 2015)

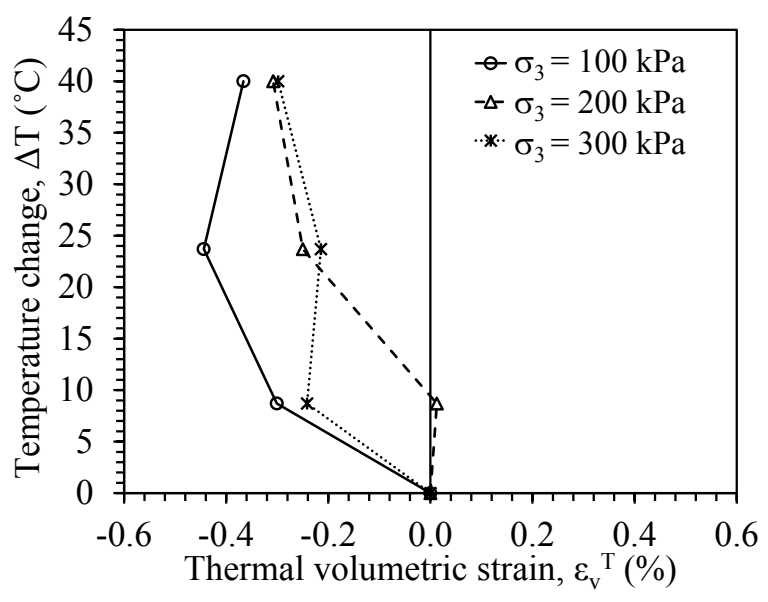

Figure 5. Thermal volume changes of specimens heated under suction magnitudes of $291 \mathrm{MPa}$ (Alsherif and McCartney 2015)

\subsection{Vega and McCartney (2015)}

The thermal volume changes measured by Vega and McCartney (2015) are shown in Figure 6. For normally consolidated specimens $(\mathrm{OCR}=1)$, contraction was consistently observed during heating. As the OCR increased, a transitional behavior to expansion was observed. As heating and cooling cycles were applied, a slight increase in expansion or contraction was observed in each of the tests. This is consistent with observations of Campanella and Mitchell (1968) and Burghignoli et al. (2000). The cyclic increase is greater for specimens that are closer to normally consolidated conditions. This is a feature that cannot be captured using thermo-elastoplastic models, but may be considered using a thermal creep model.

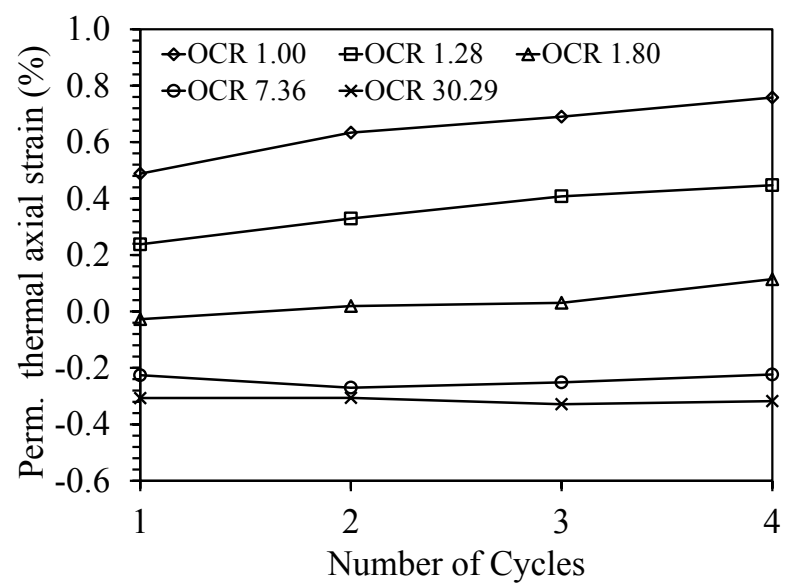

Figure 6. Thermal volume changes for specimens with different initial degrees of saturation (Vega and McCartney 2015)

The rate of thermal axial strain with change in temperature for the results from Vega and McCartney (2015) are compared with those from Alsherif and McCartney (2015) in Figure 7. In order to make the comparison in this figure, the mean effective stress and mean effective preconsolidation stress for the high suction tests of Alsherif and McCartney (2015) were back-analysed by Alsherif and McCartney (2016) using a thermo-elasto-plastic model. When plotted in terms of the effective stress OCR, similar behavior is noted for the saturated and unsaturated specimens, regardless of the fact that the specimens tested by Alsherif and McCartney (2015) were under very high suction magnitudes and those tested by Vega and McCartney (2015) are saturated. This indicates that an effective stress analysis of thermal volume change tests is critical to correctly interpret trends in the data.

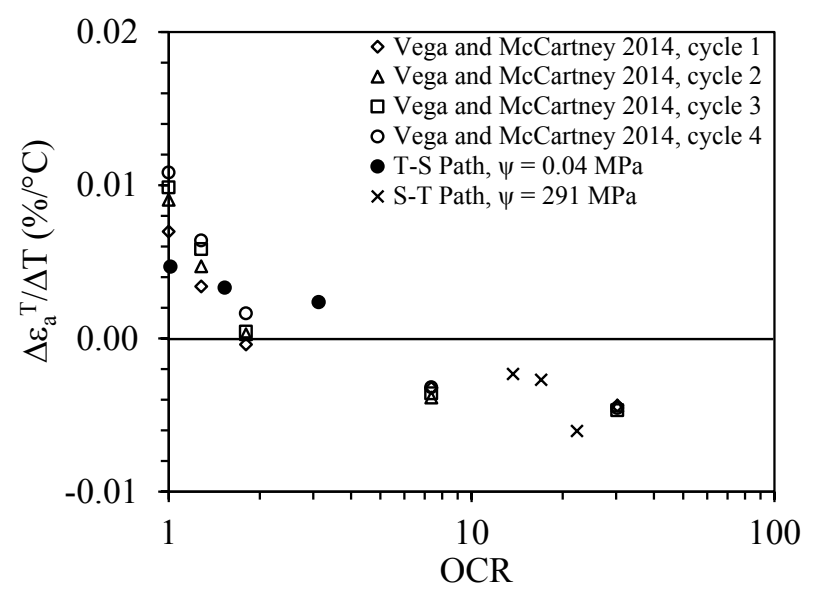

Figure 7. Thermal volume changes for specimens with different initial degrees of saturation (Alsherif and McCartney 2016) 


\subsection{Shanina and McCartney (2016)}

The thermal axial strains measured by Shanina and McCartney (2016) for different initial degrees of saturation and principal stress ratios are shown in Figure 8. The specimens were compressed isotropically to the same mean effective stress corresponding to normally consolidated conditions, after which the specimens were loaded further in the major principal stress direction while the minor principal stress was maintained constant to reach different principal stress ratios.

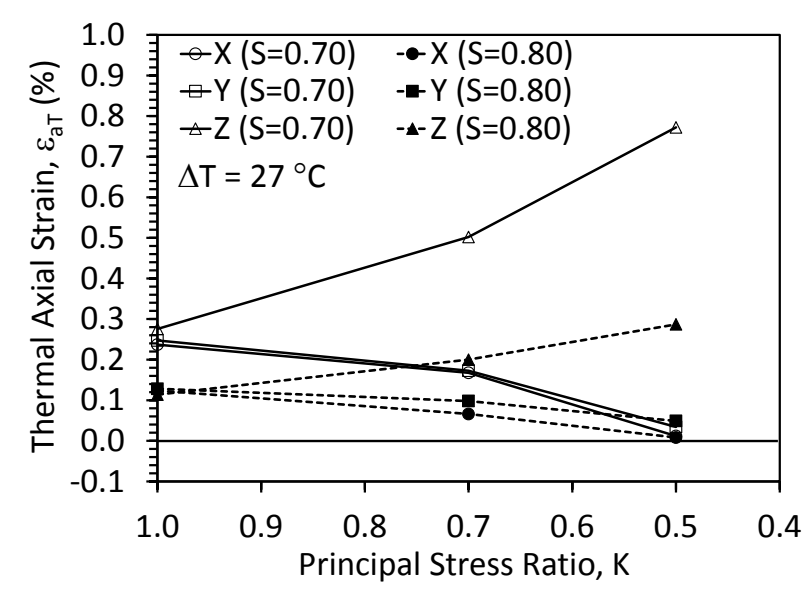

Figure 8. Thermal axial strain changes for specimens with different initial degrees of saturation and principal stress ratios (Shanina and McCartney 2016)

As the principal stress ratio decreases, the thermal axial strain in the major principal stress direction for the same change in temperature increases. The opposite is true for the thermal axial strains in the minor principal stress direction. This behavior may have interesting effects on thermally active structures in the field, as the geostatic stresses are typically anisotropic. This implies that expansion may occur in the horizontal direction (minor principal stress direction) while contraction may occur in the vertical direction (major principal stress direction).

The thermal volumetric strains for the same tests described in Figure 8 are shown in Figure 9. Different from the results of Coccia and McCartney (2016b), a clear increasing trend is observed in the magnitude of thermal volume change with decreasing degree of saturation. However, a difference between the tests of Shanina and McCartney (2016) and Coccia and McCartney (2016b) is that Shanina and McCartney (2016) performed tests on specimens compacted to different initial degrees of saturation, while Coccia and McCartney started with the same compaction conditions for all tests and used the axis translation technique to change the degree of saturation. Accordingly, the trends in thermal volume change with different initial degrees of saturation observed in Figure 9 may be due to the initial soil structure induced by compaction. At the same time, all of the specimens evaluated in this figure are all compacted wet of optimum, so this inconsistency may still be due to thermally-accelerated creep.

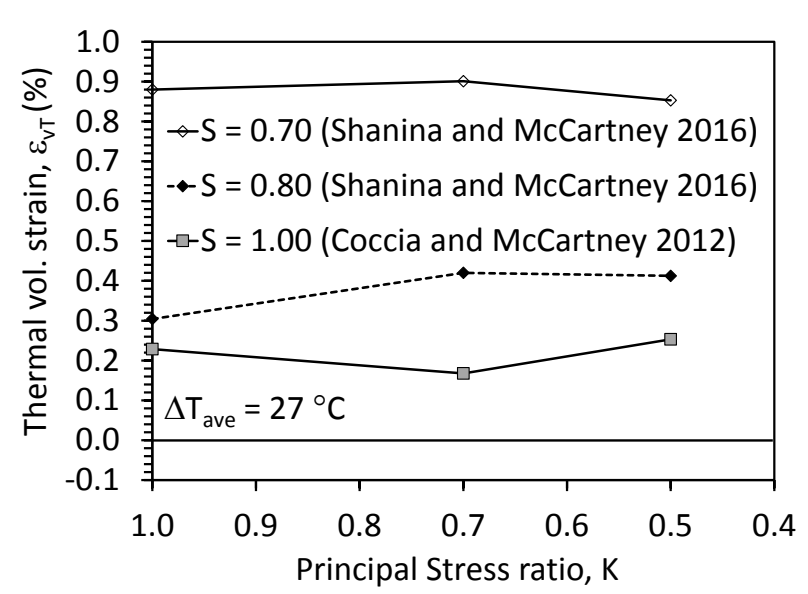

Figure 9. Thermal volumetric strain changes for specimens with different initial degrees of saturation and principal stress ratios

An interesting observation from the results in Figure 9 is that the thermal volumetric strains are not sensitive to the principal stress ratio. This indicates that the opposite trends in the thermal axial strains in the major and minor principal stress directions offset so that the overall volumetric response does not change with initial stress anisotropy. The data from Coccia and McCartney (2012) for saturated specimens of the same silt are also shown in Figure 9 for comparison, and similar conclusions can be drawn. The results in The implication of the insensitivity of the thermal volumetric strain to anisotropic stress states is that the results obtained from isotropic thermal volume change experiments can be combined with an empirical model for the role of the principal stress ratio to account for the impact of stress-induced anisotropy (Shanina and McCartney 2016).

\section{Discussion and Conclusions}

The comparison of results from the same soil but different initial conditions presented in this paper confirms that the thermal volume change of compacted, unsaturated soils is complex and can be affected by many different parameters and testing paths. The initial void ratio and compaction conditions do not strongly affect the thermal volume change results. Although some of the results appear to follow trends indicating that they may be evaluated using an elasto-plastic type model with suction hardening and thermal softening, other results are not consistent. Specifically, the lack of a trend in thermal volume change with the initial degree of saturation and the continued thermal volume change upon multiple heating and cooling cycles indicates that other analyses may be needed to predict the thermal volume change of unsaturated soils, including thermally-accelerated creep models. Another common theme in the comparison of results is that thermal volume change tests must be interpreted in terms of effective stress. Interpretation of results in terms of effective stress was observed to permit unification of the thermal volume change behavior of the soils in both saturated and unsaturated conditions. 


\section{Acknowledgements}

This author would like to acknowledge financial support of this work from NSF grants CMMI-0928159 and CMMI-1054190.

\section{References}

1. Alsherif, N.A. and McCartney, J.S. (2015). "Nonisothermal behavior of compacted silt at low degrees of saturation." Géotechnique. 65(9), 703716. DOI: 10.1680/geot./14-P-049.

2. Alsherif, N. and McCartney, J.S. (2016). "Yielding of silt at high temperature and suction magnitudes." Geotechnical and Geological Engineering. 1-14. 10.1007/s10706-015-9961-X.

3. Coccia, C.J.R. and McCartney, J.S. (2012). "A thermo-hydro-mechanical true triaxial cell for evaluation of the impact of anisotropy on thermallyinduced volume changes in soils. " ASTM Geotechnical Testing Journal. 35(2), 227-237.

4. Coccia, C.J.R. and McCartney, J.S. (2015). "Highpressure thermal triaxial cell for evaluation of the impact of temperature on soil volume change mechanisms." ASTM Geotechnical Testing Journal. In press.

5. Coccia, C.J.R. and McCartney, J.S. (2016a). "Thermal volume change of poorly draining soils I: Critical assessment of volume change mechanisms." Computers and Geotechnics. In review.

6. Coccia, C.J.R. and McCartney, J.S. (2016b). "Thermal volume change of poorly draining soils II: Constitutive modelling." Computers and Geotechnics. In review.

7. Shanina, M. and McCartney, J.S. (2016). "Impact of stress-induced anisotropy on the thermal volume change of unsaturated silt." Soils and Foundations. In review.

8. Vega, A. and McCartney, J.S. (2015). "Cyclic heating effects on thermal volume change of silt." Environmental Geotechnics. 2(5), 257-268.

9. Abuel-Naga, H.M., Bergado, D.T., Bouazza, A. and Ramana, G.V. (2007). "Volume change behaviour of saturated clays under drained heating conditions: Experimental results and constitutive modeling. " Canadian Geotechnical Journal. 44, 942-956.

10. Baldi, G., Hueckel, T., and Pelegrini, R. (1988). "Thermal volume changes of the mineral-water system in low-porosity clay soils." Canadian Geotechnical Journal. 25, 807-825.

11. Burghignoli A., Desideri A., and Miliziano S. (2000). "A laboratory study on the thermomechanical behaviour of clayey soils." Canadian Geotechnical Journal. 37, 764-780.

12. Campanella, R.G., and Mitchell, J.K. (1968). "Influence of temperature variations on soil behavior." Journal of the Soil Mechanics and Foundation Engineering Division. 94(SM3), 9-22.
13. Cekerevac, C., and Laloui, L. (2004). "Experimental study of thermal effects on the mechanical behavior of a clay." International Journal for Numerical Analytical Methods Geomechanics. 28, 209-228.

14. Cui, Y.J., Le, T.T., Tang, A.M., Delage, P., and Li, X.L. (2009). "Investigating the time-dependent behaviour of boom clay under thermomechanical loading." Géotechnique. 59(4), 319-329.

15. Cui, Y. J., Sultan, N., and Delage, P. (2000). "A thermomechanical model for clays." Canadian Geotechnical Journal, Vol. 37, No. 3, pp. 607-620.

16. Demars, K.R., and Charles, R.D. (1982). "Soil volume changes induced by temperature cycling." Canadian Geotechnical Journal. 19, 188-194.

17. Hueckel, T., and Baldi, M. (1990). "Thermoplasticity of saturated clays: Experimental constitutive study." Journal of Geotechnical Engineering. 116(12), 17781796.

18. Romero, E. (1999). Characterization and ThermoHydro-Mechanical Behavior of Unsaturated Boom Clay: An Experimental Study. Ph.D Thesis, Technical University of Catalonia, Department of Geotechnical Engineering and Geosciences, Spain.

19. Romero, E., Villar, M.V., and Lloret, A. (2005). "Thermo-hydro-mechanical behaviour of two heavily overconsolidated clays." Engineering Geology. 81, 255-268.

20. Saix, C., Devillers, P., and El Youssoufi, M.S., (2000). "Éléments de couplage thermomécanique dans la consolidation de sols non saturés." Canadian Geotechnical Journal. 37, 308- 317.

21. Salager, S., François, B., El Youssoufi, M.S., Laloui, L., and Saix, C. (2008). "Experimental investigations of temperature and suction effects on compressibility and pre-consolidation pressure of a sandy silt." Soils and Foundations. 48(4), 453-466.

22. Sultan, N., Delage, P. and Cui, Y.J. (2002), "Temperature effects on the volume change behavior of Boom clay." Engineering Geology. 64, 135-145.

23. Tang, A.M., Cui, Y.J., and Barnel, N. (2008). "Thermo-mechanical behaviour of a compacted swelling clay." Géotechnique. 58(1), 45-54.

24. Tavallali, A., Tang, A.M., and Cui, Y.J. (2007). "Thermo-hydro-mechanical behaviour of compacted bentonite." Experimental Unsaturated Soil Mechanics. Vol. 112, 259-265.

25. Towhata, I., Kuntiwattanakul, P., Seko, I., and Ohishi, K. (1993). "Volume change of clays induced by heating as observed in consolidation tests." Soils and Foundations. 33(4), 170-183.

26. Uchaipichat, A., and Khalili, N. (2009). "Experimental investigation of thermo-hydromechanical behavior of an unsaturated silt." Géotechnique. 59(4), 339-353.

27. Burghignoli A., Desideri A. and Miliziano S. (2000). "A laboratory study on the thermomechanical behaviour of clayey soils." Canadian Geotechnical Journal. 37: 764-780. 